\title{
Impact of climate change vulnerabilities on horticultral produciton
}

\begin{abstract}
Climate changes and global warming is the gigantic concern of world. Due to rising of carbon dioxide concentration, temperature, ozone, raining and drought are among the most important issues associated with climate changes. These issues could directly or indirectly impact on production and quality of fresh fruits, vegetables and other crops. The establishing of commercial agriculture varieties performed poorly in an unpredictable behavior due to abnormality of climate that influence plant growth, flowering, fruit setting, ripening and product quality, High level of green houses gases in atmosphere has directly or indirectly effects on postharvest quality and causes different physiological disorders agriculture products. Climate change also influence on plant diseases, comprehensive analysis of how climate change will affect plant diseases in agricultural systems is presently limited information available. This review present information about the potential impact of climate on fresh fruit and vegetable production, food contamination, food safety and adaptation strategies. There is a need for uses of hi-tech horticulture and advanced management of natural recourses, changing food safety situation, developing new resistant varieties which as well tolerant to high temperature will be the key adaptation strategies to address emerging risks associated with climate change.
\end{abstract}

Volume I Issue 2 - 2017

\author{
Muhammad Azam,' Rashad Qadri,' Saeed \\ Ahmed,' Muhammad Muzammil Jahangir,' \\ Muhammad Imran Khan, ${ }^{2}$ Liaqat Ali, ${ }^{3}$ M \\ Awais Ghani' \\ 'Institute of Horticultural Sciences, University of Agriculture, \\ Pakistan \\ ${ }^{2}$ Institute of Soil and Environmental Sciences, University of \\ Agriculture, Pakistan \\ ${ }^{3}$ The Islamia University of Bahawalpur, Pakistan
}

Correspondence: Muhammad Azam, Institute of Horticultural Sciences, University of Agriculture, Faisalabad, 38040, Pakistan, Email muhammad.azam@uaf.edu.pk

Received:September II, 2017| Published: October 18, 2017

\section{Introduction}

Climate change is one of the most leading environmental problems which is facing the modern world, and directly or ultimately to human action that changes the arrangement of the global atmosphere. Emission of increasing amount of greenhouse gases, carbon dioxide, methane, chlorofluorocarbons and nitrous oxide are responsible for generating changes to global climate. These changes are responsible for rise in sea level, rainfall sequences and movement of climatic regions due to increased temperatures. ${ }^{1,2}$ With the rapid development in the industrialization, increasing level of carbon dioxide from 280 ppm to $380 \mathrm{ppm}$ due to deforestation and substantial use of fossil fuels. ${ }^{3}$ It has been projected that to the end of this century $\mathrm{CO}_{2}$ will top $700 \mathrm{ppm}$ or more, whereas global temperature will increase by 1.8 to $4.0^{\circ} \mathrm{C}$ with an overall average increase of $2.8^{\circ} \mathrm{C}$ in temperature. ${ }^{4}$ The global warming affected plant vigor, fruit bearing ability, decrease in size of fruits, low colour development, less juice content, decrease shelf-life, and increased pests attack resulting in poor quality and low production in apple crop. ${ }^{5}$

Climate change has also adverse effect on Pakistan agriculture, and 47 percent of people directly or in directly depends on the earning form agriculture which contributes 21 percent to the GDP. ${ }^{1}$ It has been projected that a rise in 3 degrees by 2040 and up to 5-6 degrees by the end of the century. Pakistan rank $28^{\text {th }}$ among those countries which are highly influenced by climate change, while listed at $12^{\text {th }}$ highly exposed countries in the World Bank report. ${ }^{6}$ Currently, Pakistan is facing floods due to heavy and irregular rain patterns. ${ }^{7,8,4}$ There is need to study the how climate variable affects the agriculture production, profitability, and need to adapt the new tools to avoid the odd impact of climate change. ${ }^{1}$ Allen et al. ${ }^{9}$ observed that elevated $\mathrm{CO}_{2}$ increased the biomass growth of plant about 2.6 fold with increasing temperature to the large growth enhancements in sour orange trees. Garg et al. ${ }^{10}$ investigated $60 \mathrm{~F} 1$ hybrids, 15 parent lines with four mutant homozygotes and observed quality attributes and nutritional quality under high temperature conditions. Quality attributes found higher in mutant homozygotes, whereas significantly higher lycopene content observed in 60 hybrids than their respective mid-parental values. Four mango cultivars were exposed to low temperature to induce flowering and transferred to controlled conditions for 20 days in glasshouse. High temperature increased the inflorescence in four cultivars, whereas low temperatures caused morphological changes in flower structures in all cultivars, and significant changes observed in 'Kensington'. ${ }^{11}$ Chmielewski et al. ${ }^{12}$ observed potential effect of climate change on the phenological phases of natural vegetation, fruit plants and field crops in the last decade of $20^{\text {th }}$ century. Plant growth and development has been strongly shifted. Increased temperature showed lower changes of development phases in late spring and summer. A change in plant development is still moderate so less impact on yield processes. In the future, climate change may show strong impact on low yield production. Olesen et al. ${ }^{13}$ found that climate change produced positive effects on agriculture with introduction of new crop species and varieties with higher crop production and expansion of suitable areas for crop cultivation in northern areas. Plant protection, nutrient leaching and the soil organic matter may be required more for higher production. However, possible increase in water shortage and extreme weather which may cause low yield, higher variability and reduction in traditional crops in southern areas. Potential impact of climate change (high temperature, elevated carbon dioxide and ozone) which directly and indirectly effect the fresh fruit and vegetable production. High temperature, carbon dioxide and high accumulation of ozone can potentially affect photosynthic rate and changes in physiochemical properties and quality attributes, and causing tuber malformation and scabs on potatoes. ${ }^{14}$

The plant phenology is significantly changed by global climate change because temperature affects the timing of development, both through interactions and alone with other cues, such as photoperiod. ${ }^{15,16}$ Quick climatic changes ability to change the adaptability of temperate crops and fruit in the future, and might increase severe production 
problems. ${ }^{17}$ Climate change has adverse effect on insect population in pollination. If there is very low temperature or either very high there is no fertilization, thus disturbing fruit setting. For cross pollinated fruits such as pistachios and walnuts, inadequate chilling can decrease pollination directly to reduced crop yields. ${ }^{18}$ It revealed that changes in rainfall supply can affect year-to-year differences at flowering, quality and productivity in tropical fruits. ${ }^{19}$ In some cases, crop failures may frequently occur, and also observed lower yield and early senescence of trees. ${ }^{20}$ Fruit and vegetable growth and development are impacted by several environmental aspects. Moretti et al. ${ }^{21}$ presented that hot temperatures disturb photosynthesis ultimately causing changes in $\mathrm{C}_{6} \mathrm{H}_{12} \mathrm{O}_{6}$, flavonoid contents, organic acids, antioxidant activities and firmness. The biochemical reactions fundamental for normal cell function in plants will disrupts by high temperature stress. It primarily affects the photosynthetic functions of higher plants. ${ }^{22}$ Maximum temperatures could be caused significant losses in productivity of tomato, reduced fruit set, lower and smaller quality fruits..$^{23,24}$

Climate change reduces the quality of fruit and vegetables as well. Major problem in the tropics is rind color of low carotenoid development and harm of chlorophyll contents due to severe temperatures. Therefore, fruit in the tropics stand pale and greenish, mandarins and oranges, in particular, do not achieve their beautiful rind color. In fall decline in air and soil temperatures scripts the start of color changes in subtropical regions. ${ }^{25}$ Fruit peel showed less $\mathrm{H}_{2} \mathrm{O}$ content, tender and hardening due to moisture loss under drier climate when compared desert grown fruit and coastal in California. ${ }^{26}$ For effective ecosystem, there is need for the identification of appropriate genetic resources for use in climate change areas. It might be better to develop good production systems, which can improve their economic power. ${ }^{27}$ Diverse genetic resources can play an important role in this for adaptation to changing conditions through natural selection or human interventions. It is very important to understand how climate changes will effect on agriculture production in future. ${ }^{28-33}$

\section{Acknowledgments}

I would like to acknowledge the contribution of Bashert Ali and Tariq Khatana for reviewing this manuscript.

\section{Conflict of interest}

The author declares no conflict of interest.

\section{References}

1. Usman Shakoor, Abdul Saboor, Ikram Ali, et al. Impact of climate change on agriculture: Empirical Evidence from arid region. Pak J Agri Sci. 2011;48(4):327-333.

2. Singh HP. Impact of climate change on horticultural crops. In: Challenges of Climate Change-Indian Horticulture, Westville Publishing House, India; 2010. p. 1-8.

3. Capiati DA, País SM, Téllez Iñón MT. Wounding increases salt tolerance in tomato plants: evidence on the participation of calmodulin-like activities in cross tolerance signically. J Exp Bot. 2006;57(10):23912400 .

4. IPCC. Climate change, the physical science basis. In: Solomon S, editor. Contribution of Working Group I to the Fourth Assessment Report of the Intergovernmental Panel on Climate Change. USA: Cambridge University Press; 2007. p. 1-996.

5. Jangra MS, Sharma JP. Climate resilient apple production in Kullu valley of Himachal Pradesh. International Journal of Farm Sciences. 2013;3(1):91-98.
6. MoE. Climate Change Vulnerabilities in Agriculture in Pakistan. Ministry of Environment, Government of Pakistan, Annual Report. 2009;p. 1-6.

7. Eid HM, Marsafawy SM El, Ouda SA. Assessing the economic impacts of climate change on agriculture in Egypt: a Ricardian Approach. Policy Research Working Paper, World Bank, USA; 2007. p. 1-4293.

8. Kurukulasuriya P, Mendelsohn R. Crop switching as an adaptation strategy to climate change. African Journal of Agricultural and Resource Economics. 2008;2:105-126.

9. Allen LH, Joseph CVV. Carbon dioxide and high temperature effects on growth of young orange trees in a humid, subtropical environment. Agricultural and forest meteorology. 2009;149(5):820-830.

10. Naveen Garg, Devinder SC. Assessment of fruit quality attributes of tomato hybrids involving ripeing mutants under high temperature conditions. Scientia Horticulturae. 2011;131:29-38.

11. Sukhvibul N, Whiley AW, Smith MK, et al. Effect of temperature on inflorescence and floral development in four mangos (Mangifera indica L.) cultivars. Scientia Horticulturae. 1999;82(1,2):67-84.

12. Chmielewski Frank M, Müller A, Bruns E. Climate changes and trends in phenology of fruit trees and field crops in Germany, 1961-2000. Agricultural and Forest Meteorology. 2004;121(1,2):69-78.

13. Olesen Jørgen E, Marco Bindi. Consequences of climate change for European agricultural productivity, land use and policy. European Journal of Agronomy. 2002;16(4):239-262.

14. Moretti CL, Mattos LM, Calbo AG, et al. Climate changes and potential impacts on postharvest quality of fruit and vegetable crops:A review. Food Research International. 2010;43(7):1824-1832.

15. Bernier G. The control of floral evocation and morphogenesis. Ann Rev Plant Physiol Plant Mol Biol. 1988;39:175-219.

16. Partanen J, Veikko K, Heikki H. Effect of photoperiod and temperature on the timing of bud burst in Norway spruce (Picea abies). Tree Physiol. 1998;18(12):811-816.

17. Ameglio T, Alves G, Bonhomme M, et al. Winter functioning of walnut: Involvement in branching processes. In: Arbre L, editor. Biologieet development, Isabelle Quentin, Canada; 2000. p. 230-238.

18. Gradziel TM, Lampinen B, Connell JH, et al. Winters' Almond: An Early-Blooming, Productive, and High-quality Pollinizer for' Nonpareil'. HortScience. 2007;42(7):1725-1727.

19. Sapii AT, Norlia Y, Muda P, et al. Postharvest quality changes in Dokong (Lansium domesticum Corr.) harvested at different stages of ripeness. Proceeding of the $19^{\text {th }}$ ASEAN/ $1^{\text {st }}$ APEC Seminar on Postharvest Technology. Vietnam; 1999. p. 1-52.

20. Oukabli A, Mahhou A. Dormancy in sweet cherry (Prunus avium L.) under Mediterranean climatic conditions. BASE. 2007;11(2):133-139.

21. Moretti CL, Mattos LM, Calbo AG, et al. Climate changes and potential impacts on postharvest quality of fruit and vegetable crops: A review. Food Research International. 2010;43(7):1824-1832.

22. Weis E, Berry JA. Plants and high temperature stress. Symp Soc Exp Biol. 1988;42:329-346.

23. Stevens MA, Rudich J. Genetic potential for overcoming physiological limitations on adaptability, yield, and quality in tomato. HortScience. 1978;13:673-678.

24. Yamaguchi T, Blumwald E. Developing salt-tolerant crop plants: challenges and opportunities. Trends Plant Sci. 2005;10(12):616-619.

25. Young LB, Erickson LC. Influence of temperature on color change in Valencia oranges. Proc Am Soc Hot Sc. 1961;78:197-200.

26. Monselise SP, Turrell FM. Tenderness, climate and citrus fruit. Science. 1959;129(3349):639-640. 
27. Coping with climate change-the roles of genetic resources for food and agriculture. Food and Agriculture Organization of United Nations, Italy; 2015. p. $1-130$.

28. Awasthi RPM, Verma HS, Sharma RD, et al. Causes of low productivity in apple orchards and suggested remedial measures: Productivity of temperate fruits. In: Jindal KK, editor. 2001. p. 1-8.

29. Leon HA, Joseph CVV. Carbon dioxide and high temperature effects on growth of young orange trees in a humid, subtropical environment Agricultural and Forest Meteorology. 2009;149(5):820-830.

30. Luedeling E, Girvetz EH, Semenov MA, et al. Climate change affects winter chill for temperate fruit and nut trees. PLoS One. 2011;6:e20155.
31. Cohen A, Lomas J, Rassis A. Climatic effects on fruit shape and peel thickness in 'Marsh Seedless' grapefruit. J Am Soc Hort Sci. 1972;97:768-771.

32. Naveen G, Devinder SC. Assessment of fruit quality attributes of tomato hybrids involving ripening mutants under high temperature conditions. Scientia Horticulturae. 2011;131:29-38.

33. Smith IN. Trends in Australian rainfall-are they unusual? Australian Meteorological Magazine. 2004;53(3):163-173. 